\title{
ASSESSMENT OF TOURISM ENTREPRENEURS' EXPOSURE TO NATURAL DISASTERS: A CASE STUDY OF RANAU EARTHQUAKE (2015)
}

\author{
AK MOHD RAFIQ AK MATUSIN*1, CHAMHURI SIWAR ${ }^{2}$ AND SHARINA ABDUL HALIM ${ }^{2}$ \\ ${ }^{1}$ Faculty of Built Environment and Surveying, Universiti Teknologi Malaysia, Johor, Malaysia. ${ }^{2}$ Institute for Environment and \\ Development, Universiti Kebangsaan Malaysia, Selangor, Malaysia
}

*Corresponding author: akmohdrafiq@utm.my

Submitted final draft: 18 May $2020 \quad$ Accepted: 26 May $2020 \quad$ http://doi.org/10.46754/jssm.2020.12.013

\begin{abstract}
Earthquake is a destructive and unavoidable natural disaster. It struck Ranau District, Sabah in 2015 that caused severe physical damages. Vulnerability studies have been conducted following the earthquake yet focused on tourism context is still limited. Thus, a fundamental question asked is to what extent Ranau Tourism entrepreneurs were exposed to the 2015 earthquake event. This study aimed to explore the exposure of Ranau tourism entrepreneurs to the 2015 earthquake disaster. A qualitative approach was conducted through in-depth interviews, passive observation and secondary data. Thematic analysis was applied manually to organise the data, which was controlled by the Vulnerability Framework for Sustainable Tourism Development (VFSTD). As for the results, Ranau tourism entrepreneurs showed a significant level of exposure to the 2015 earthquake disaster which Source component revealed to have higher exposure level than Power component. Implicitly, it showed strength and weakness capitals fabricated within Ranau tourism entrepreneurs that characterise their exposure level to the 2015 earthquake disaster. Consequently, this study encapsulates important information for preparatory steps to embrace the impacts of the earthquake especially to Ranau tourism, in turn, enhance their development sustainability in the future. It is also recommended to further the vulnerability analysis for sensitivity and adaptation elements under this case
\end{abstract}

Keywords: Tourism sustainability, tourism vulnerability, entrepreneurs, exposure, natural disasters, earthquake, source, power.

\section{Introduction}

Tourism sector has been recognised as one of the economic development agents that is continuously growing globally. This is depicted through the number of international tourist arrivals as World Tourism Organization (2018) reports an increase of $7 \%$ or approximately 1.3 million arrivals in 2017 and the momentum is expected to increase at $4 \%$ to $5 \%$ in 2018 . Significantly, this arrival flow becomes one of main contributors for foreign currency exchange (WTO 2013) especially to the community that heavily depends on nature resources as their main livelihood sources (Guo et al., 2018).

Undoubtedly, a natural disaster is a detrimental event, and it is unavoidable. It becomes a challenge for tourism as it distorts tourism sustainability including tourism products, activities, infrastructure and community (Kato 2017; Orchiston, 2013;
Tsai \& Chen 2010). In turn, tourism activities are closed until recovery phase is completed, alternately affecting the community economy that relies highly on tourism revenues (Kato, 2017). Orchiston (2012) responded to the challenge by advocating the integration of natural disaster management as one of main ingredients in sustainable tourism development. In tourism context, Faulkner (2001) defines natural disaster management as "in response to the near certainty of experiencing a disaster of some type eventually, tourism organisations can devise means for minimising the damage of and accelerating the recovering from such event through the development of disaster management strategies". In fact, the failure to integrate natural disaster management into sustainable tourism development will give wrong understanding to the fundamental concept of sustainability (Espiner et al., 2017). 
Adger (2006) added vulnerability approach as preparatory steps in natural disaster management towards the sustainable development goal. Vulnerability approach basically is a study of exposed unit (household, human group, ecosystem, community) vulnerable to exposed hazards and capability (or incapability) of exposed unit to cope, recover or adapt (Kasperson et al., 2012). There are three core elements in vulnerability approach: Exposure, Sensitivity and Adaptation (Turner et al., 2003; Jiang \& Liu, 2009; Webersik et al., 2010). Therefore, as tourism industry faces the challenges of natural disasters, the integration of natural disaster management into tourism development and management will foster thorough fundamentals of sustainable tourism development.

\section{The Case of Ranau Earthquake 2015}

An earthquake of 6.1 magnitude struck Ranau District, Sabah in June 2015 at the scale of VII (very strong) (United State Geological Survey 2015). The epicentre was located approximately
$7 \mathrm{~km}$ NNE of Kundasang Town and $13 \mathrm{~km}$ NW of Ranau Town with depth of $10 \mathrm{~km}$ (Felix Tongkul, 2015) - Figure 1. In fact, Ranau Earthquake 2015 is the first and strongest earthquake that had happened at the scale of VII recorded in Malaysia (Felix Tongkul et al., 2017).

Felix Tongkul et al. (2017) and Felix Tongkul (2015) revealed the primary impacts of the earthquake including physical damage of public infrastructure, schools, hostels, houses, mosques, churches and water tanks. While secondary impacts such as damage to water catchment, mud flood and shortage of water supply (Felix Tongkul et al. 2017; Felix Tongkul, 2015). Some lives were lost among the climbers of Mount Kinabalu due to the earthquake. (Matusin et al., 2019a). Thereupon, several vulnerability studies have been conducted following the Ranau earthquake disaster such as the study on building element damages (Mohd Irwan et al., 2017), characterisation of seismotectonics activities (Rabieahtul Abu Bakar et al., 2015), structural deformation modelling (Dora et al., 2018), analysis of school building

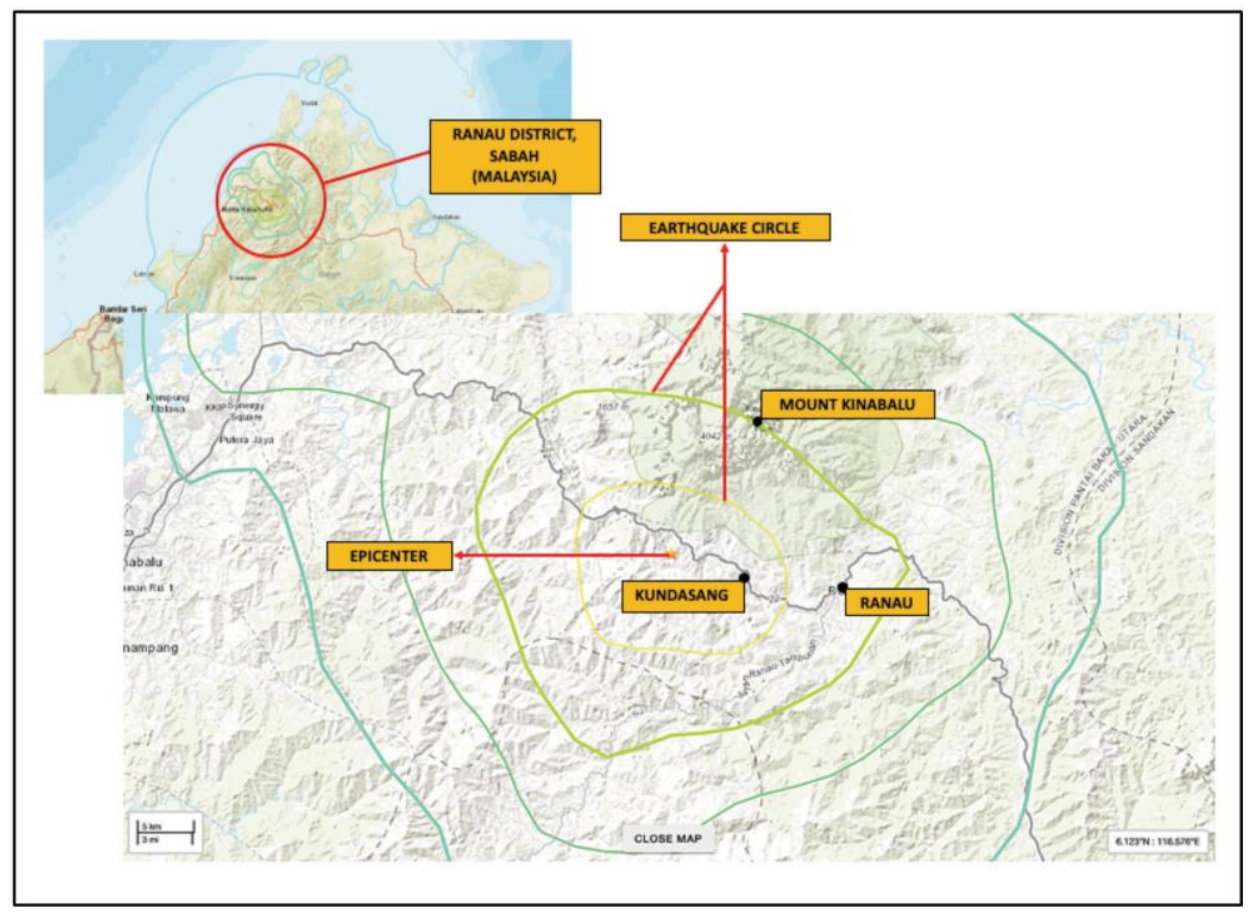

Figure 1: Ranau 2015 earthquake-based map

Source: United State Geological Survey (2015) 
damages (Takano \& Saito, 2017), Earthquake Vulnerability Assessment - EVAS (Indan et al., 2018), knowledge and readiness towards earthquake (Singh et al., 2018), impact on small business performance (Noor Fzlinda Fabeil et al., 2018) and trauma dissociative experience and coping response (Allya Cassandra et al., 2017). However, a focused vulnerability study in tourism context following the Ranau earthquake 2015 is still limited. Whereas tourism is one of the main drivers of economic development and economic resource for the Ranau District (Ranau District Office 2011, 2015). Any detrimental changes occur to Ranau tourism will affect the local socio-economic too. For instance, tourist visits took a downturn at Kinabalu Park as was recorded after the earthquake on June, 2015 in which the numbers dropped below 10000 from July-September when compared to other quarters (Sabah Park 2018) - See Table 1.

In principle, Becken and Hughey (2013) emphasise tourism as a vital sector for economic and local community development and hence brings the need for active involvement in disaster risk reduction activities so as to cope with natural disaster. Jiang and Ritchie (2017) also explained that natural resources and culture are the main tourism products and attraction while any devastation on them will affect tourist demand and eventually lead to economic downturn. Orchiston (2012) empirically verified that an earthquake is able to unhook the fundamental dimension of sustainable development (nature, economy, social). This is further exacerbated by the tendency of the tourism sector to be less prepared to handle natural disasters strike (Prideaux et al., 2003). Thus, the importance of natural disaster management integration into sustainable tourism development (Orchiston, 2012) must be encouraged. Therefore, it is very crucial to study Ranau tourism vulnerability following the 2015 earthquake to reorganise, restructure and rearrange Ranau tourism activities and finally enhance their revenues and development sustainability while facing natural disasters.

Thus, a fundamental vulnerability question arises: To what extent were Ranau Tourism entrepreneurs exposed to the 2015 earthquake event? The aim of this study was to examine the exposure of Ranau tourism entrepreneurs to 2015 earthquake disaster. Significantly, Ranau tourism entrepreneurs are the primary tourism community that have executed Ranau's tourism activities and its development for years. Indeed, tourism entrepreneurs are the main pillar in contribution to Ranau tourism development sustainability and any alteration happening to them will also affect Ranau tourism directly. Importantly, this study will bring a progressive research and innovative development to tourism industry in Malaysia. As sustainable tourism concept applied in this country is more to green tourism concept that focuses on conservation and economy equity, the integration of natural disaster management into tourism development at national or regional level will enhance a thorough fundamental concept of sustainable tourism development.

\section{Vulnerability Approach}

Vulnerability approach is a functioning set approach to determine and monitor vulnerability process in time to time and from place to another place and build up a strategy for risk reduction (Rygel et al. 2006). Vulnerability approach embodies a sophisticated understanding to context, agency, equity, justice and power (Eakin \& Luers, 2006; O'Brien, 2006). The core understanding of this approach is a multidimensional socio-political process that creates reactions to risk and changes as well as the form

Table 1: Number of visitors at Kinabalu Park in 2015

\begin{tabular}{lcccc} 
Tourist & January-March & April-June & July-September & October-December \\
\hline Local & 129,161 & 108,719 & 68,869 & 149,986 \\
\hline International & 26,811 & 19,952 & 23,230 & 16,494 \\
\hline Total & 155,972 & 128,671 & 92,099 & 166,480 \\
\hline
\end{tabular}

Source: Sabah Park (2018) 
of changes in socio-ecological system including system's strength, values and ideologies, knowledge and culture norms (Miller et al,. 2010). While, Berkhout (2008) explained that the vulnerability approach embraces resilience to change, trade deal between human groups, systems, level and scale and narrative used by actor or institution to acquire credibility, legitimation, authority and power. Vulnerability approach can also be seen as a normative translation of risk reduction activities to keep a balance in existence socio-ecological system (Adger, 2008). It becomes more relevant in a condition when risks have been identified in a population or an institution (Nelson et al., 2007).

On the other hand, vulnerability approach is likely to support the social dimension within socio-ecological system beyond the geophysical domain, in turn, eliminating biophysical life support system that plays vital role in sustaining a development (Miller et al., 2010). This approach also emphasises the needs of continuous interaction within multi groups (and multi agendas) as an important and rational segment in creating population characteristics although the patterns or trends of a population are usually based on local characteristics (Rigg et al., 2008). Importantly, the effort of vulnerability approach to highlight the significance of a context is performed through detailing the mechanism of system creation, the space being disputed and mechanism of various agendas and relationships among stakeholders (actors in tourism products production and distribution) that affect tourism vulnerability (Calgaro et al., 2014).

In tourism context, tourism destination vulnerability to shock-stress either in terms of socio-economy or environmental has been discussed in tourism research corpus and tourism industry players (Sharpley, 2005). Various incidents have been identified that influence tourists' inflows including economic downturn (Prideaux et al., 2003), disease outbreaks such as hand-foot and mouth disease, bird flu (avian influenza), Severe Acute Respiratory Syndrome (SARS) (Miller and Ritchie 2003), terrorist attack (Baker \& Coulter, 2007) and natural disasters such as earthquake (Nyaupane \& Chhetri, 2009; Orchiston, 2013; Kato 2017). Those destructive events do not occur separately. Instead, the incidents that are threats to tourism destinations are inextricably linked with broad socio-ecological context shaped by multiple drivers of change simultaneously (Dwyer et al., 2008).

Tourism sector also relies highly on consumer expenditure changes and recreational selection patterns (Higgins-Desbiolles, 2010), which exacerbate tourism vulnerability especially, when tourism becomes a popular choice as development agent in limiting resources areas (Baker \& Coulter, 2007). This becomes a challenge for tourism industry that is highly dependent on well-being, relaxation and consumer expenditure (Lew, 2003). Thus, it is crucial for tourism sector to give more attention on preparation to deal with the risks or uncertainties, alternately elevate the needs of vulnerability study in tourism field. Adger (2006) also emphasized the significant of vulnerability study as an effective analytical tool to explore the degree of vulnerability to hazards, inefficiency and marginalisation of both social and physical systems and as analysis guidance to enhance well-being through risk reduction activities. Thus, the vulnerability approach in tourism is a progressive initiative to understand the multi-dimensional process and interactions that fabricate the tourism system through time and space and the mechanism of tourism system to respond to the changes, modification or uncertainties that breakthrough system border.

\section{Vulnerability Analysis Framework}

A framework for vulnerability analysis in sustainability science by Turner et al. (2003) is used to depict the fundamental understanding of vulnerability approach. This framework recognises several aspects such as population characteristics, variety of stresses absorbed into the population, factors that influence population sensitivity to shock-stress and population ability to respond and adapt (Turner et al., 2003). In fact, this framework stimulates sustainability 
through the synergy of its dimensions namely, (1) Exposure, (2) Sensitivity and (3) Adaptation - coping response and adjustment (Turner et al., 2003, 2010). Importantly, the fundamental principle of vulnerability in this framework is the interaction of two main components namely Source and Power where both components play a role in shaping the vulnerability of a system (Birkmann, 2006). Basically, Source is referred to the environment while Power is represented by human (Calgaro Lloyd \& Dominey-Howes, 2014).

Vulnerability is conceptualised and composed of multi-dimensional asset in integrated human-environment system and it is widely expanding within the system approach (Turner et al., 2003; Adger, 2006; Eakin \& Luers, 2006; O’Brien 2006). In fact, human evolution and social-ecological environment are formed through interplay of different components (such as human, technology, organisational and biophysical) that operate and change in evolutionary system (Pelling, 2010). The acceptance of relationship between human activity and inseparable biophysical processes has increased the need for equal attention in sustainability research especially through relation of human processes creating their environment and vice versa (Clark \& Dickson, 2003). Consequently, vulnerability in sustainability science perspective is contextualised and defined as an integrated system of human-environment that are influenced by interaction between biophysics, socio-political, economic, institutional and technological conditions (Turner et al., 2003).

Adaptation of Turner vulnerability analysis to determine the tourism destination vulnerability is well-established (Vogel \& O'Brien, 2004). In fact, inherent hazards in tourism system and its surrounding can be identified through Turner-based vulnerability analysis (Becken et al., 2014). Besides, its ability to identify an individual or group's exposure, sensitivity and resilience to shock is closely related to the destination's accessibility and eligibility to the existences resources that surround it (Calgaro \& Lloyd, 2008). Matusin et al. (2019b) proposed Vulnerability Framework for Sustainable Tourism Development (VFSTD) that aims to determine the vulnerability of tourism destination affected by natural disaster or hazards towards sustainability (Figure 2). There are four elements constructed in VFSTD - Shocks-Stressors, Exposure, Sensitivity and System Adaptiveness, at the same time it incorporates both components of Sources and Power to represent human-environment relationship (Matusin et al. 2019b). Yet, this framework still needs more empirical study to elevate its effectiveness. Thus, the objective of this study is to determine the exposure of Ranau tourism entrepreneurs to 2015 earthquake using VFSTD that is translated through Sources and Power components.

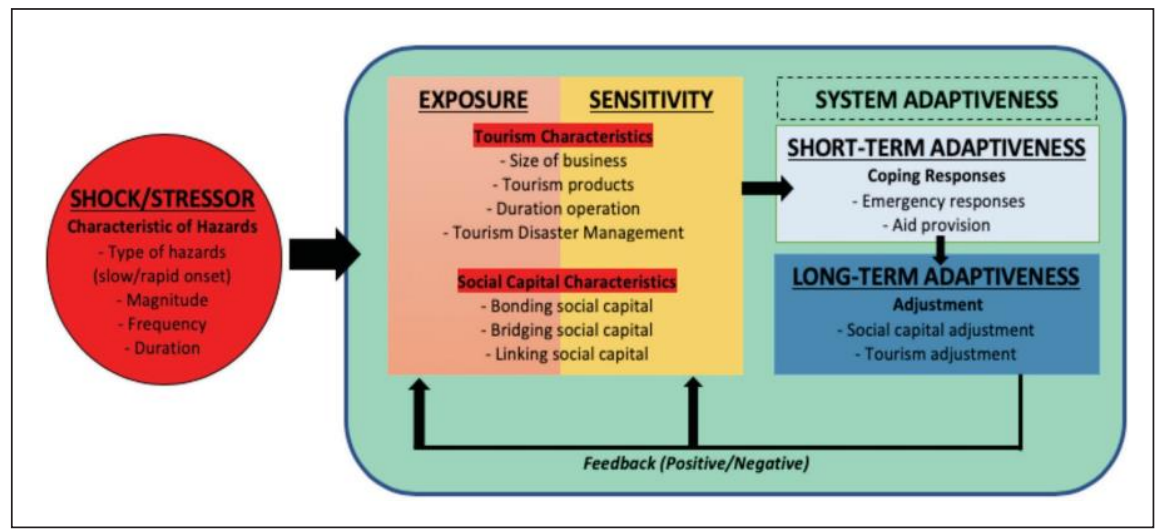

Figure 2: Vulnerability framework for sustainable tourism development (VFSTD)

Source: Matusin et al. (2019b) 


\section{Exposure Element}

Pelling (2003) defined exposure as a physical product of a location and environmental features either constructed or natural. Exposure is also adapted as level of an exposed unit (who or what) responds to shock or stress (Clark et al., 2000). On the other hand, Calgaro and Lloyd (2008) perceived exposure as nature of terrain, placement and types of development. Importantly, Exposure element plays vital role to determine system risk level to natural disasters which also acts as risk indicator (Tsao and Ni 2016). Hence, this study concludes that Exposure element is a group of characteristics or condition that influences the system, which can make them either stronger or more vulnerable. Consequently, both Source and Power components are integrally executed into Exposure element to determine the exposure of Ranau tourism entrepreneurs to the 2015 earthquake disaster (Figure 3) using the VFSTD.

\section{Source Component}

Source component in vulnerability analysis is a specific place-and system, dynamic and varied, high scaled, character of population, facing various stress and capacities to response and change constantly (Adger, 2006). In tourism context, production or preparation of tourism product is influenced by destination image which possesses interaction between multi-stage of enterprise and service including facilities, guides, marketing, operations and life spans which takes place at multilevel (Dredge \& Jenkins, 2003). In VFSTD, contextualisation of tourism to represent Source component is significant, especially in community-based tourism as their products are characterised by their destination image including natural resources as well as local culture (Matusin et al., 2019b).

In addition, destructive events such as natural disaster, political instability and disease outbreaks also affect tourist's perception on actual situation or anticipation of safety risks to events regardless whether it arises from the destination itself or from the outside (Ritchie, 2008). Besides, fragility of tourism destinations is further exacerbated by high reliance on visitor inflows (Cohen, 2008) and consumer expenditure (Higgins-Desbiolles, 2010) as tourism products is the main source of revenue (Sharpley, 2005). Baker and Coulter (2007) emphasized that if there was no adjustment to reduce vulnerability in tourism, then it should not be a driver for sustainable development. Thus, natural disaster management becomes an important component in sustainable tourism development. Therefore, VFSTD enumerates items in Sources component including Tourism Products, Tourism Size, Tourism Expectancy and Natural Disaster Management (Matusin et al., 2019b).

\section{Power Component}

Power component in VFSTD is contextualised through social capital (Matusin et al., 2019b). Social capital is fundamentally shaped by structure of relationships within social relationships (Coleman, 1988) that benefit

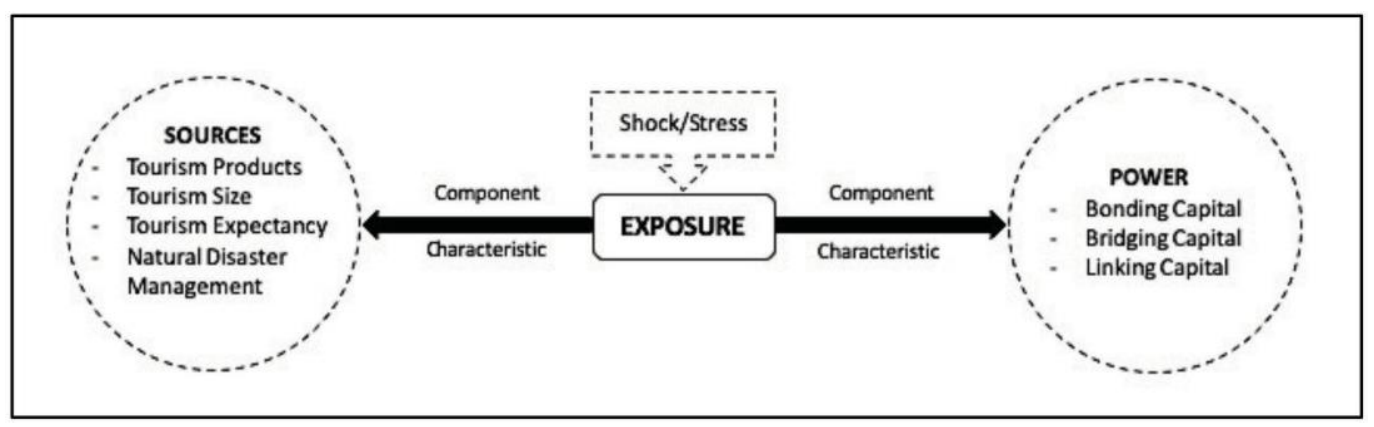

Figure 3: Exposure element of vulnerability analysis framework

Source: Matusin et al. (2019b) 
individuals and groups (Liu et al., 2014). Portes (2000) added the basic idea of social capital including family members, friends and allies or groups which is an important asset during crisis. In tourism perspective, social capital is a stronghold for tourism destinations to deal with catastrophe (Hwang \& Stewart, 2017). Guo et al. (2018) explained that social capital is capable to of providing a valuable theoretical perspective to the study of adaptation mechanism and tourism community resilience. In fact, social capital is a vital component for sustainable tourism development (Taylor, 2017; Dickinson et al., 2017) and foundation for collaboration success and governance efficiency towards sustainable tourism (Nunkoo, 2017).

In natural disaster perspective, social capital plays a critical role in post-disaster recovery process for tourism destinations through three mechanisms, namely bonding social capital, bridging social capital and linking social capital (Szreter \& Woolcock, 2004). Bonding social capital referred to as strong internal relationships within emotionally connected individuals such as family members and relatives (Ruiu et al., 2017). Bridging social capital is defined as external relationship among different individuals including those from the neighbourhoods or other tourism operators (Guo et al., 2018). While linking social capital is a vertical network that reflects the relationship of trust in a particular jurisdiction and serves to mobilize resources and power (Poortinga, 2012). Accordingly, these three types of social capital are itemised to represent Power in VFSTD and applied in this study.

\section{Methods}

\section{Research Paradigm and Methodology}

This study relied on constructivism which postulates interactions that occur within world physical and human surrounding it and interpreted technically through social science research (Blaikie, 2010). Creswell (2014) emphasized that constructivists tend to build on a definition that is more subjective based on their experience, and in turn, lead them to explore a subject more broadly rather than narrowing it down into a few limited categories. Consequently, a qualitative methodology with a case study were applied to explore and understand the meaning of individual and group under study (Creswell, 2014). The rationale of qualitative approach is due to its ability to derive the results to understand a small phenomenon but well-known or to obtain deeper data that may be difficult to quantify through quantitative study or to gain new perspectives on something already publicly known (Maxwell, 2005).

\section{Data Collection}

This study was conducted in the RanauKundasang areas, a famous tourist destination and the most affected areas following the Ranau earthquake 2015 (USGS 2015, Felix Tongkul, 2015). Respondent criterion is tourism entrepreneurs or managers in the KundasangRanau areas that were affected by the 2015 earthquake disaster. To sample the respondents, a combination sampling technique of purposive sampling and snowball sampling was applied. Purposive sampling is a selection technique that meets respondent criterion while snowball sampling is applied to expand respondent selection that has similar criteria through suggestion of previous respondents (Chua, 2014). In accordance with the study aim, an indepth and semi-structured interview technique (face-to-face) was used for data collection. This technique is useful to obtain rich and substantively meaningful data (Campiranon $\&$ Scott, 2014). Data collection began with indepth interview session of targeted respondents that meet respondent criterion (via purposive sampling). Then, this process continued with potential respondents that were suggested by the initial group of respondents (via snowball sampling).

Data collection started from early September to the end of October 2018, with 30 participants having been completely audio recorded. Data collection reached saturation point when respondents began to provide similar responses. Guest et al. (2006) explained that if the research 
goal is to interpret a shared perception, belief or behaviour among a relatively homogeneous group, then a relatively small sample will likely be satisfactory. Increasing number of respondents would not improve the quality of research findings. Overall, the interview duration ranged from 55 minutes to 1 hour and 20 minutes. All the answers given were recorded using a voice recorder. Figure 4 and Table 2 detail the location of respondents and are grouped based on village.

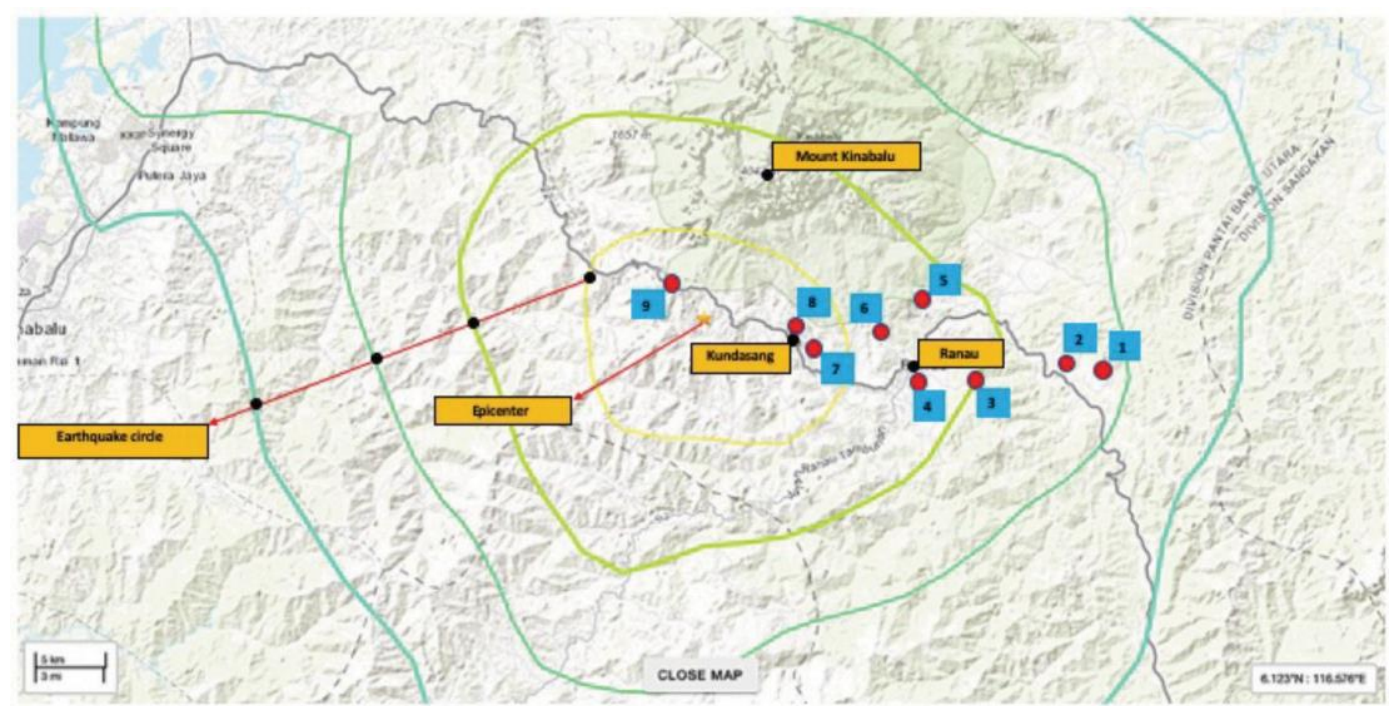

Figure 4: Location of respondents (based on village)

Source: Fieldwork 2018

Table 2: List of respondents' villages

\begin{tabular}{clc}
\hline Number & Village-Town & $\begin{array}{c}\text { Number of } \\
\text { Respondents }\end{array}$ \\
\hline 1 & Nalapak Village - Ranau & 1 \\
\hline 2 & Luanti Baru Village - Ranau & 2 \\
\hline 3 & Marakau Village - Ranau & 1 \\
\hline 4 & Ranau Town & 2 \\
\hline 5 & Poring Village - Ranau & 1 \\
\hline 6 & Mesilau Village - Kundasang & 14 \\
\hline 7 & Sinisian Village - Kundasang & 7 \\
\hline 8 & Kundasang Town - Kundasang & 1 \\
\hline 9 & Kinabalu Park - Kundasang & Total Number of Respondents \\
\hline
\end{tabular}

In accordance with the research questions, two fundamental interview questions were asked directly: (i) What are the components of tourism aspect (Source) prior to the 2015 earthquake and what are their characteristics? (ii) What are the components of social capital (Power) bonded within Ranau tourism prior to the 2015 earthquake and what are their characteristics? 


\section{Data Analysis}

A complete verbatim transcript was used to analyse the results (Veal 2011). A thematic analysis was executed to organise qualitative data manually, as it is a fundamental and flexible analysis for qualitative data (Braun \& Clarke, 2006). Braun and Clarke (2006) established six basic phases in thematic analysis: (1) Familiarising the data, (2) Initial coding, (3) Searching for themes, (4) Reviewing themes, (5) Defining and naming themes, and (6) Producing report. The fundamental template of thematic analysis in this study was based on controlled variables items in both Source and Power components as mentioned in the framework earlier. These controlled variables drive the sequence of findings accordingly to answer the research questions.

To increase the validity, this study followed Creswell's (2014) approach by providing direct quotes and thick descriptions to convey a set of detailed findings. This refers to the contents pointed out by respondents during the interview. Meanwhile, reliability in qualitative research can be understood as having consistent research approach across different stages (Creswell, 2014). A proper procedure by Braun and Clarke (2006) was executed during the thematic analysis to ensure all qualitative data went through the same procedure and structuralised based on the controlled variables of framework. In addition, passive observation during fieldwork and secondary data were also used to enhance the reliability of the findings.

\section{Results}

Findings and discussion are presented based on controlled variables outlined earlier: Source (Tourism Products, Tourism Size, Tourism Expectancy, Natural Disaster Management) and Power (Bonding Capital, Bridging Capital, Linking Capital). Figure 5 depicts the overall results of thematic analysis of exposure for both Source and Power component.

\section{Source: Tourism Product}

The first controlled variable of Source component is Tourism Product which revealed the type or characteristic of Ranau tourism products. Indepth interview with respondents revealed three themes, namely Diversity, Reception, Quality.

\section{Theme 1: Diversity}

This theme described a variety of Ranau tourism products offered to their tourists such as food and beverage, leisure activity, ecotourism, environmental conservation and accommodation

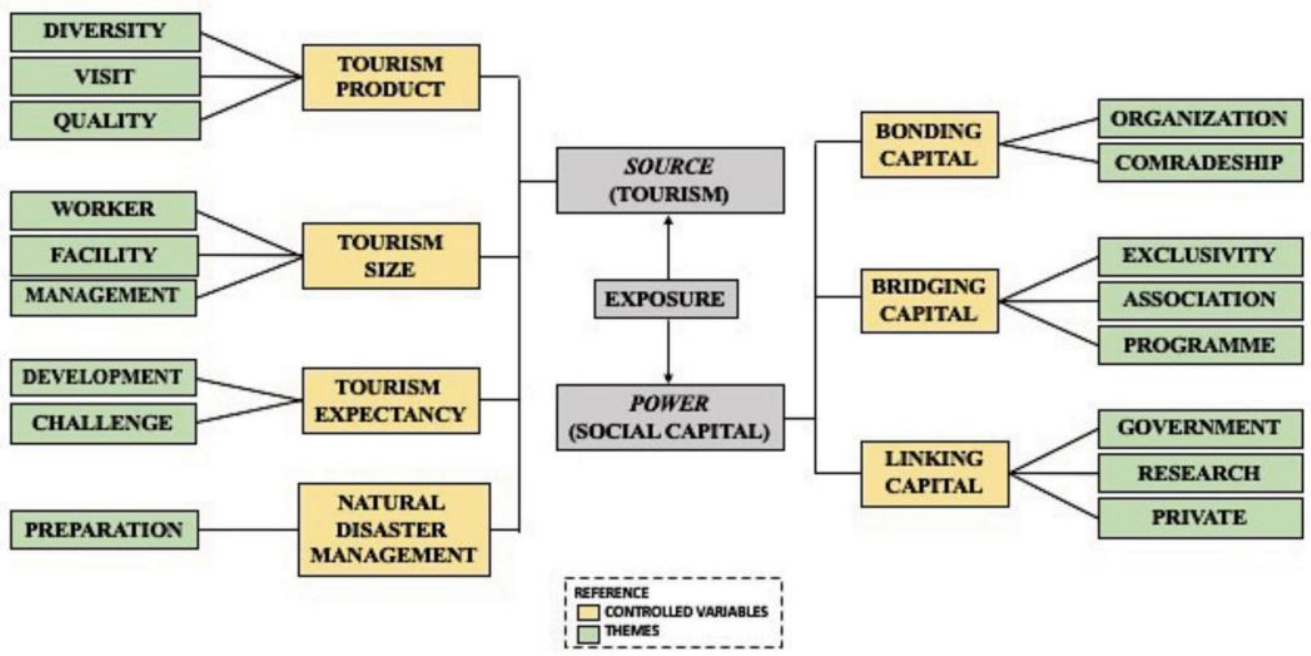

Figure 5: Thematic analysis of Ranau tourism's exposure (source and power component) to the 2015 earthquake 
as well as cultural activities prior to the 2015 earthquake disaster. This study also recognised that Ranau tourism products were characterised mainly based on local culture and traditions which are expressed through the development of community-based tourism, CBT. The uniqueness that coloured Ranau tourism products, in turn, attracts more tourists to visit Ranau. It was stated that: "we maintained the Homestay concept, so we provide family activities package, traditional food and clothes. We give them the experience of Dusun culture lives" (R6-KD). Figure 6 shows Tagal activity (fish massage) that becomes one of the main tourism attractions in Ranau.

\section{Theme 2: Visit}

This theme explained the encouraging visits to Ranau, which are illustrated through the increasing number of tourists visiting Ranau's tourism destinations every year especially before the earthquake. This indicated that Ranau is one of the main tourist destinations in Sabah. It was in line with the statement of following respondent: "before the 2015 earthquake, we had a yearly increase in tourists' arrivals" (R4RN). Figure 7 depicts the statistics of tourist visits to Kinabalu Park (Sabah Park, 2018).

\section{Theme 3: Quality}

This theme described quality control of the development of tourism products in Ranau that went through several evaluation phases, including supervision and monitoring from Sabah Ministry of Tourism, Culture and Environment (KePKAS). The evaluation was conducted to maintain the quality and safety standard compliance for Ranau tourism products before being offered for to tourists. It was explained by the following respondent: "we have completed several seminar and course before the ministry handed the certificate to us" (R11-KD).

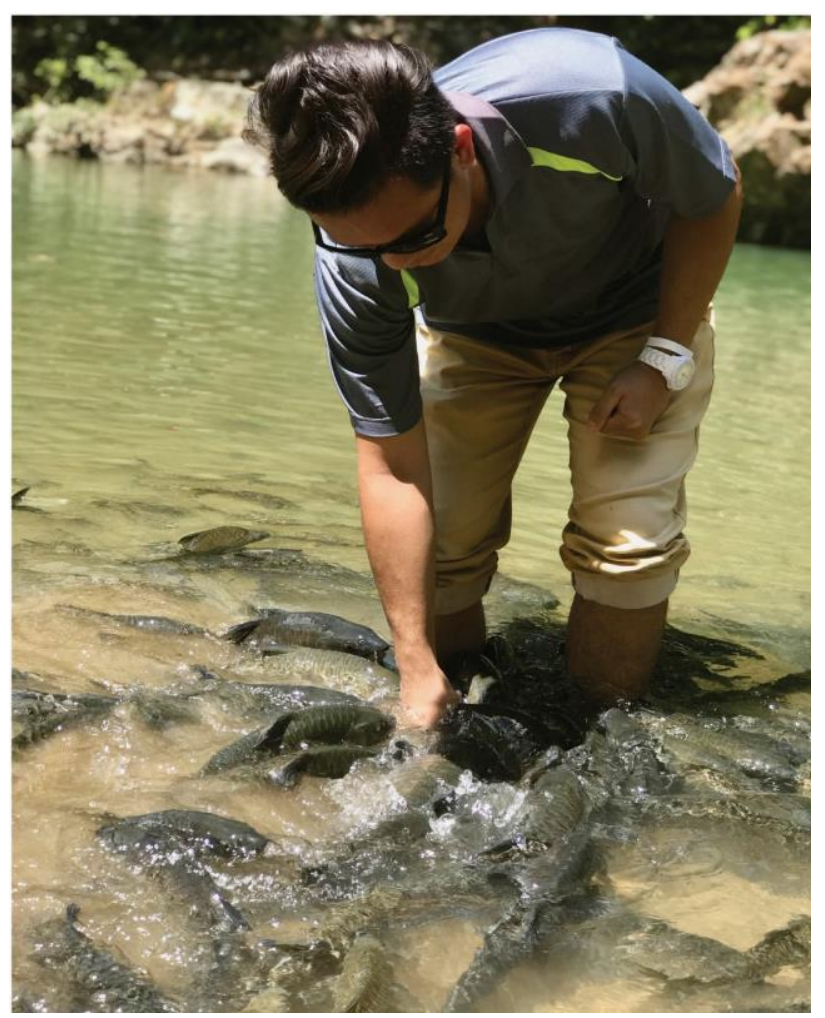

Figure 6: Tagal activity (fish massage) in Luanti Village, Ranau

Source: Fieldwork 2018 


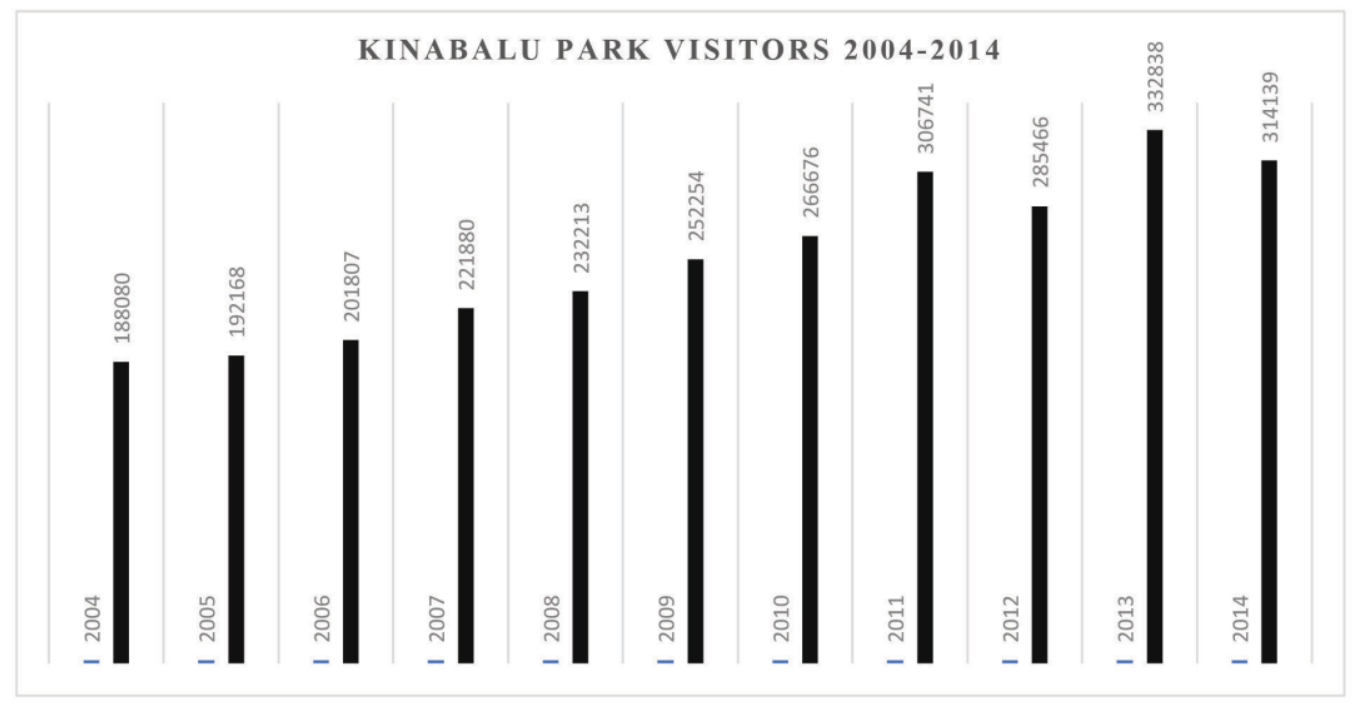

Figure 7: Number of visitors at Kinabalu Park

Overall, Tourism Products variables revealed the diversity of Ranau's tourism products that are fabricated and rooted based on local culture and tradition especially the Dusun tribe. The uniqueness of this diversity eventually attracted consistent visits by local and international tourists for years. To retain their quality, Ranau tourism products were consistently monitored and assessed by the authority.

\section{Source: Tourism Size}

The second controlled variable for Source component is Tourism Size which detailed the operation capacity of Ranau tourism before the 2015 earthquake disaster. Three themes were elicited under Tourism Size: Worker, Facility, Management.

\section{Theme 1: Worker}

This theme showed the capacity of employees of Ranau's tourism business. The majority of respondents, 93 percent, felt that the current number of their workers was adequate, while the remaining respondents (7 percent) indicated otherwise (insufficient number of workers). The capacity of employees was dependent on the size of their operations (either small or large business) and the number of tourists' visits to Ranau. In addition, 80 percent of the respondents were hiring their own family members (particularly private small-scale business), while 20 percent were hiring the local community (large-scale business). This was quoted in the following statement: "our employees are among our family members too. So far, it enough to do all the tasks and works" (R8-KD).

\section{Theme 2: Facility}

This theme explained capacity of facilities provided by the respondents before the 2015 earthquake disaster. Particularly, 80 percent of the respondents were satisfied with their facilities prior to the 2015 earthquake, another 20 percent felt their facility was still insufficient to accommodate the increasing number of tourists, especially during the peak season. This included the facilities that were still under development or reconstruction at that time. One participant noted that: "our facilities are still not enough to run our activities and it needs to be top up" (R4-RN).

\section{Theme 3: Management}

The third theme under Tourism Size is Management which detailed the operations 
management carried out by Ranau tourism entrepreneurs. Based on the interview, all the respondents stated that they formed their own organisational chart to handle their operation and sorted multiple tasks to different units accordingly. This was stated in the following statement: "the staffs in every section has been divided accordingly, the office, ticketing, and activities. The staff in charge will complete their tasks and solve the problems of their unit. Any unresolved problems, they will refer to us" (R2$\mathrm{RN})$.

The Tourism Size indicated the capacity of employees of Ranau tourism, depending on the business scale and the majority of the employees were hired from among family members and the local community. Besides, the facility of for tourism activities in Ranau was also capable to of supporting the overall demands. In fact, the tourism operation and management in Ranau, either small- or large- scale businesses, were structured via organisational chart.

\section{Source: Tourism Expectancy}

The third controlled variable under Source component is Tourism Expectancy which refers to Ranau tourism operation period and their development pattern before the 2015 earthquake. Two themes identified under Tourism Expectancy are: Development and Challenge.

\section{Theme 1: Development}

This theme described the development pattern and journey of Ranau tourism (before the earthquake). The majority of the 87 respondents explained that they had started a tourism business that was long drawn out at the beginning with fewer tourist visits in the early 90s. It was aggravated by lack of main infrastructures such as roads and other tourism facilities at that time, lack of support from the local people in the 90s due to the negative perception on tourism that would threaten local serenity as well as low awareness on the economic benefits of tourism. However, the development pattern was changed in the 2000s when Ranau received vast tourism facilities and products development followed by the eruption of tourist arrivals. This had increased local people economy indirectly. The following respondent shared the experience: "tourism has changed a lot here and then boosted the economy of the local people. That the most significant impact" (R2-KD).

\section{Theme 2: Challenge}

This theme depicted the challenges encountered by Ranau tourism before the 2015 earthquake. About 83 percent of the respondents encountered the physical constraint such as downslopeupslope mountainous geographical surface that caused difficulties to development activities in Ranau. Besides that, the majority of 95 percent of the respondents revealed the water shortage crisis encountered by all Ranau locals including the tourism community. In addition, Ranau tourism was also confronting illegal tourism operations, especially illegal Homestay. The problems arose when the illegal Homestay defied the rules and regulation set by Sabah tourism ministry which could give negative image to the tourists. It was shared by this respondent: "we knew there are many unregistered Homestays operating here and any bad thing happened to them literally would affecting us too" (R9-KD)

Tourism Expectancy showed the development pattern of Ranau tourism overall that had dealt with many obstacles at the beginning and progressive changes in early 2000s until now. Ranau tourism also faced local challenges including geographical constraint and illegal tourism operation that could decelerate tourism development activities in Ranau.

\section{Source: Natural Disaster Management}

The final controlled variable of Source component is Natural Disaster Management which outlined the status of natural disaster management for Ranau tourism prior to the 2015 earthquake disaster. There is only one theme formed under this variable - Preparation. 


\section{Theme 1: Preparation}

Based on the interview, all respondents confirmed that they did not have any form of preparation or management especially for risks or natural disasters in their tourism development, management and activities (prior to 2015 earthquake). In fact, there was no necessity or obligation for them to establish a natural disaster management at that time. Instead, they assumed the experience they had in managing their operation could prepare them to deal with any shocks. It was shared by one of the respondents: "in my opinion, we have nothing to say about management for natural disasters before. It is never ever been in our mind to do so" (R11-KD).

Overall, score for themes outlined under exposure of Source component is enumerated in Table 3. The score indicates that Source component of Ranau tourism entrepreneurs have significant level of exposure to the 2015 earthquake disaster with 58 percent (more than 50 percent), and the Natural Disaster Management variable showed higher level of exposure, followed by Tourism Expectancy (medium level of exposure), while both Tourism Product and Tourism Size variables have lower level of exposure.

\section{Power: Bonding Capital}

The first controlled variable in Power component is Bonding Capital which details inner relationship of Ranau tourism entrepreneurs prior to the 2015 earthquake disaster. According to in-depth interviews with respondents, this study had identified two themes under Bonding Capital: Organisation and Comradeship.

\section{Theme 1: Organization}

About 33 percent of respondents explained that their bonding capital existed structurally in the form of organisation that range from top management to supporting administration especially in large-scale tourism businesses. Whereas, 67 percent of respondents stated their bonding capital was formed through the relationships amongst their family members that participated in the business. This respondent shared the opinion: "we are often assisted by our own family. I used to call them to in charge" (R24-KD).

\section{Theme 2: Comradeship}

Based on the interview, this theme confirmed that all the respondents had strong relationship with their workers. Indeed, they aggrandised the

Table 3: Scores of Ranau tourism exposure to the 2015 earthquake disaster for source component

\begin{tabular}{|c|c|c|c|}
\hline Controlled variables & Themes & Characteristic & Exposure \\
\hline \multirow{3}{*}{ Tourism Product } & Diversity & Strength & \multirow{3}{*}{ Low } \\
\hline & Visit & Strength & \\
\hline & Quality & Strength & \\
\hline \multirow{3}{*}{ Tourism Size } & Worker & Strength & \multirow{3}{*}{ Medium } \\
\hline & Facility & Strength & \\
\hline & Management & Strength & \\
\hline \multirow{2}{*}{ Tourism Expectancy } & Development & Strength & \multirow{2}{*}{ Medium } \\
\hline & Challenge & Weakness & \\
\hline Natural Disaster Management & Preparation & Weakness & High \\
\hline \multicolumn{4}{|l|}{ Calculation Score } \\
\hline Level & Score & Overall Score & \multirow[b]{2}{*}{$1+1+2+3=7$} \\
\hline Low & 1 & Source exposure score & \\
\hline Medium & 2 & \multirow[t]{2}{*}{ Source exposure percentage } & \multirow{2}{*}{$58 \%$} \\
\hline High & 3 & & \\
\hline
\end{tabular}


sense of family relationships and maintained good communication between workers and other units. This theme also described high level of cooperation among the workers which can be seen through the activities such as communal work. It was quoted in this statement: "it is our culture to work together even with other units, we will always give our cooperation" (R3-KD).

Thus, Bonding Capital variable constitutes the form of inner relationship that existed among tourism entrepreneurs in Ranau in which the majority of it was due to family member relationships and some was formed among organisation staff. Regardless of the type of bonding capital, all the respondents believed they maintained strong relationship amongst them.

\section{Power: Bridging Capital}

The second controlled variable of Power component is Bridging Capital which explained the form of relationship (intra-relationship) in the Ranau tourism community. This variable is composed of three themes: Exclusivity,
Association and Programme.

\section{Theme 1: Exclusivity}

This theme represented the 17 respondents that did not get involved with any association especially tourism platform and about threequarter from these 17 respondents were largescale tourism business that are bound to the rules of the respective main bodies, even though, this group still maintained their passive (unofficial) relationship with other Ranau tourism business and entrepreneurs for communication and dissemination of local information. It was shared by the following respondent: "we are entitled under Sabah Parks, and any participation must obtain the approval from them. But we were still given the opportunity to take part with the local platform" (R4-RN).

\section{Theme 2: Association}

Particularly, 83 percent of the respondents were actively involved in Ranau tourism association such as Ranau Tourism Association (RATA) and Walai Tokou Association. Figure 8 shows the organisation chart of Walai Tokou

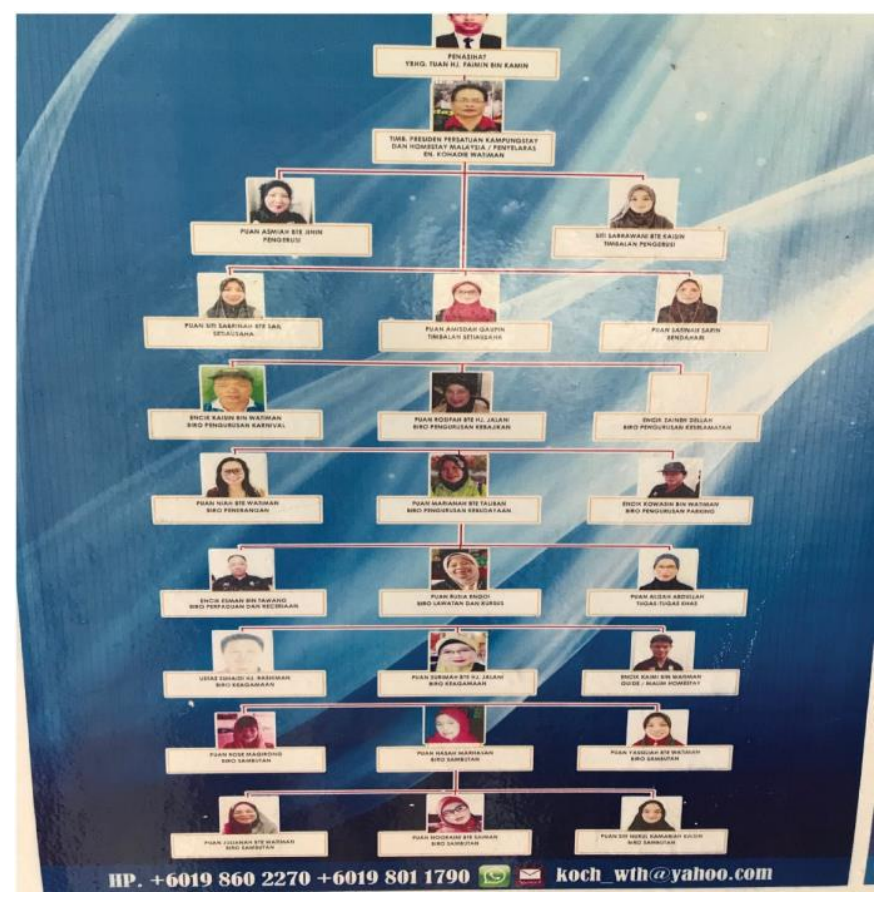

Figure 8: Walai Tokou organisation chart 
Association. Those respondents also explained that there was high level of cooperation that generated among members. It was translated through several activities such as promotion of tourism products, communal works as well as meetings and discussions regarding Ranau tourism development and activities. It was shared by this respondent: "the great thing be in this association that we are always helping and supporting each other, solve the problems together" (R15-KD).

\section{Theme 3: Programme}

This theme reflected the bridging capital of Ranau tourism that is translated through carnivals, festivals or joint programmes such as Eid Fitr Carnival, Cabbage Fiesta, Fishing Fiesta and Independence Day Celebration. All respondents agreed that everyone had giving their full cooperation and high commitment to run the programmes successfully, at the same time, enhance the relationship amongst the Ranau tourism community. It was followed by this quote: "we have so many carnivals here and together running them successfully. We even become closer to each other through the carnivals" (R28-RN).

Bridging Capital variable explains the type of intra-relationship that existed within the Ranau tourism community as a whole including respondents that took part in local tourism association, carnivals and celebrations. While few of the respondents did not participate with any local platform due to rules and regulations commitment with their main bodies.

\section{Power: Linking Capital}

The last controlled variable of Power is Linking Capital that explained inter-relationship of Ranau community with other parties either directly or indirectly. Three themes created are: Government, Research, Private.

\section{Theme 1: Government}

This theme described the forms of collaboration between Ranau tourism community with the state government as well as local authority.
The collaboration including advisory services, briefing and training on safety and health, environmental issues such as rivers and forest protection and promotion activities of Ranau tourism products. Importantly, these collaborations enhance quality control of Ranau tourism environment, safety and products. It was shared by this respondent: "the police were sent out to patrol our Homestay areas, so they keep this neighbourhood safe especially when it involves many tourists" (R20-KD).

\section{Theme 2: Research}

Linking capital in this study is also depicted through research collaborations between education institutions (local and international) and Ranau tourism entrepreneurs. The collaboration with Ranau local people is very important for researchers to facilitate their studies. In turn, Ranau tourism entrepreneurs received the benefits from the collaboration in terms of knowledge sharing that might be useful for their tourism activities and products development: "I have been working with a lecturer and students from UMS regarding bird's species in Kinabalu Park as a potential product here. I gained a lot of knowledge from them. We also get the impacts from their works" (R3-KD).

\section{Theme 3: Private}

This theme described the linking capital of Ranau tourism that was formed through the collaboration with private agencies or non-governmental organisations. This including collaboration with financial institution for financial loan purposes and local tourism agencies for promotion and marketing. This mutual collaboration provided the best opportunity for both tourism agencies and Ranau tourism entrepreneurs to develop their businesses. This was in line with what the following respondent said: "we have collaborated with so many tourism agents and they have brought hundreds of tourists in one visit. So, we have to call other Homestay to provide their rooms" (R6-KD).

Linking Capital variable showed different types of inter-relationships of Ranau tourism 
entrepreneurs with other parties including government and local authority, education institutions (for research activities) and nongovernmental bodies and private agencies (for financial purposes, promotion and marketing). This indicated open relationship or open system executed by Ranau tourism.

Holistically, the theme scores for Power component of Ranau tourism in this study revealed insignificant level of exposure to the 2015 earthquake with 44 percent (less than 50 percent). Bridging capital showed medium level of exposure, followed by linking capital and bonding capital which constituted lower level of exposure. Table 4 enumerates the themes scores under Power component.

Overall, exposure level of Ranau tourism to the 2015 earthquake disaster based on the combined scores of both Source and Power component was 51 percent. This indicated that Ranau tourism ollectively encompassed a significant exposure to the 2015 earthquake disaster with the percentage of more than 50 percent overall. Table 5 details the overall percentage of Ranau tourism exposure to 2015 earthquake disaster.

\section{Discussion}

\section{The strengths and weaknesses of Ranau tourism's Source component}

This study basically discusses the strength and weakness capitals that characterised the exposure of Ranau tourism entrepreneurs to the 2015 earthquake disaster. Basically, the inherent weaknesses are the catalyst that induces or enhances this community's exposure to the 2015 earthquake, while their strengths act as moderator to regulate the exposure and/ or as enhancer to navigate coping response. At first, their strengths in the context of Source component tare seen through the diversity of their tourism products which allowed them to increase their capacity to fulfil tourists' demands, alternately reduce pressure on one

Table 4: Scores of Ranau tourism exposure to 2015 earthquake disaster for Power component

\begin{tabular}{|c|c|c|c|}
\hline Controlled variables & Themes & Characteristic & Exposure \\
\hline \multirow{2}{*}{ Bonding Capital } & Organisation & Strength & \multirow{2}{*}{ Low } \\
\hline & Comradeship & Strength & \\
\hline \multirow{3}{*}{ Bridging Capital } & Exclusivity & Weakness & \multirow{3}{*}{ Medium } \\
\hline & Association & Strength & \\
\hline & Programme & Strength & \\
\hline \multirow{3}{*}{ Linking Capital } & Government & Strength & \multirow{3}{*}{ Low } \\
\hline & Research & Strength & \\
\hline & Private & Strength & \\
\hline \multicolumn{4}{|l|}{ Calculation Score } \\
\hline Level & Score & Overall Score & 9 \\
\hline Low & 1 & Power exposure score & $1+2+1=4$ \\
\hline Medium & 2 & \multirow[t]{2}{*}{ Power exposure percentage } & \multirow{2}{*}{$44 \%$} \\
\hline High & 3 & & \\
\hline
\end{tabular}

Table 5: Overall percentage of Ranau Tourism exposure to the 2015 earthquake disaster

\begin{tabular}{lcc}
\multicolumn{1}{c}{ Component } & Exposure & Overall Exposure Percentage \\
\hline Source & $58 \%$ & $51 \%$ \\
\hline Power & $44 \%$ & 5 \\
\hline
\end{tabular}


product only. De Roo (2012) also stated that the diversity of services and products is very important in tourism as it promotes innovation that contributes to the strength and dynamics of tourism destination. Besides that, increasing number of tourists visit to Ranau almost every year has strengthened their product marketing and income as well. Ranau tourism also showed capability in managing their workers and facilities effectively even in a peak season or holiday season. In addition, Ranau tourism entrepreneurs put their products quality standard at higher level to provide satisfaction to tourists, as Eraqi (2006) found that the quality of products and services purchased greatly affect the tourists' satisfaction and vice versa and in turn, strengthen positive image of Ranau as a destination. Dredge and Jenkins (2003) also added that tourist experiences on a tourist attraction or product is largely influenced by destination image. In terms of expectancy, Ranau tourism entrepreneurs showed their level of accuracy and consistency in terms of development pattern. This is due to their competitive nature that elevates level of survival under high competition in local tourism industry especially in Sabah State. Although Ranau tourism activities were slightly stagnant at the early phase, they still managed to develop and grow from year to year. All these are relatable to Tourism Life Cycle Model by Butler (1999) who explained a slow and steady rate at the early stage (exploration) and it is then elevated to the development phase of a tourist destination - including Ranau tourism. Consequently, these strength capitals of Source component have nurtured Ranau tourism entrepreneurs with the ability to grow and survive, eventually regulate the level of exposure to the 2015 earthquake disaster and enhance their coping response to the vulnerability.

Meanwhile, the weaknesses capitals of Ranau tourism entrepreneurs in the context of Source component can be seen firstly through high dependency on tourism activity as the main income revenue. This high dependency has lowered Ranau tourism flexibility to face shocks or pressures such as an earthquake disaster. Handmer et al. (2007) and Sharpley (2005) stated that high reliance on tourism activity as a main source of revenue can contribute to the fragility of tourism destinations. It is closely linked to the second weakness of Ranau tourism entrepreneurs which is the mountainous geographical challenges that limit their variety of resources and local development activity. In fact, any high-risk development activities and environmental-physical changes in Ranau could trigger the landslide activity. Ritchie (2008) also explained the tendency for tourism activities in highly sensitive (ecologically) and dangerous areas. Besides, Ranau tourism entrepreneurs are also exposed to illegal tourism activity especially Homestay. Illegal tourism activities in Ranau is a threat that leads to unhealthy competition in Ranau tourism development. Indirectly, it would create a negative image to local tourism. In addition, they also faced the water shortage crisis that convoluted their routine especially tourists that are highly relying on local tourism operators to provide clean water facility. Lastly, the exposure of Ranau tourism entrepreneurs to the 2015 earthquake is driven by the absence of natural disaster management in their development. They only have basic safety and emergency plan to prepare them for fire incident. Yet, risk management for disaster (such as earthquake) is different from other risk management. This is relatable with low awareness on natural disaster management among Ranau tourism community that limits their preparation on disasters overall. Cioccio and Michael (2007) emphasized that the tourism community is used to have less interest and knowledge on disaster management, thus limiting their preparation to deal with a natural disaster (Morgan \& Fluker, 2003). In fact, the failure to incorporate natural disaster management in sustainable tourism development can give misinterpretation on the fundamental concept of sustainability (Espiner et al., 2017). Therefore, the weaknesses capitals of Ranau tourism entrepreneurs would trigger their exposure level to natural disaster especially in the case of the 2015 earthquake. 
The Power of Social Capital of Ranau Tourism Entrepreneurs

In the context of Power, social capital of Ranau tourism entrepreneurs is more stable and solid compared to Source component with all of them (bonding, bridging, linking) have strong relationship. Their bonding capital showed a very strong bonding which was boosted by close acquaintances among the workers. This is related to workers demographic background when about 80 percent of respondents enlisted family members into their business, while another 20 percent of respondents were hiring the local people of Ranau. The similarity of ethnicity and languages for communication elevated the internal bonding amongst them. The bridging capital also revealed strong relationship among Ranau tourism entrepreneurs directly (association) and indirectly (programmes, neighbourhoods). Interestingly, the strength of their bridging capital is capable of encouraging Ranau tourism development although they are dealing with high competition. This illustrates their powerful unity as a system that function as a defence agent to deal and regulate any form of vulnerability. Woolcock and Narayan (2000) also explained social capital as an asset that was used to elevate community engagement in tourism, built tourism entrepreneur group, close the social gap within tourism community, unite tourism networks, collaborate in the development of tourism products and services and finally favours accountability in the decision-making process of tourism development. Aforementioned, Ranau tourism community is relying on tourism activities as their major economic resource, regardless of religion, political affiliation or competition; they need to work together to safeguard their interest and well-being of all parties involved in Ranau tourism activity. Ranau tourism entrepreneurs also showed strong inter-relationship with both government and non-governmental bodies. The linking bonding with governmental agencies is seen as the responsibility of related governmental agencies towards their duty to ensure Ranau tourism development runs smoothly, systematically, organized and committed to the rules and regulations of national and regional tourism ministry. Besides, Ranau tourism entrepreneurs also collaborated with higher education institutions for research and student activities. This is an opportunity platform for Ranau tourism to enhance their business progression through innovation and scientific studies. In terms of linking relationship with non-governmental organisation, it is translated through the symbiotic relationship for both parties. For tourism agencies, they collaborated with Ranau tourism entrepreneurs to build up their tourism package. Concurrently, Ranau tourism entrepreneurs take the opportunity to propagate their products market and as a platform for promotion. Jager et al. (2007) argued that the development of strong social capital will help to reduce the vulnerability as well as to encourage sustainable development and improve life well-being. Indeed, Taylor (2017) added that social capital is a significant component in sustainable tourism development. Holistically, this study encapsulated all three social capitals of Ranau tourism entrepreneurs as their strength modals presumed to regulate their exposure level to the 2015 earthquake disaster. These capitals are also believed to be a catalyst to drive the coping response activities towards the earthquake. In fact, Szreter and Woolcock (2004) described social capital as bringing critical purpose in recovery process aftermath of natural disasters. Guo et al. (2018) also emphasized the capability of social capital to provide theoretical perspective in studying the mechanism of tourism community adaptation and resilience. Thus, Ranau tourism entrepreneurs have successfully built a powerful preparation to address any threats especially natural disasters through their social capitals (or Power component).

\section{Conclusion}

Tourism is well-known as one of the biggest economy sectors that escalates development of economy worldwide, including Ranau tourism destination of Sabah, Malaysia. Particularly, an earthquake of 6.1 magnitude struck Ranau in June, 2015. Tourism activities were also 
inevitably affected by the earthquake. Yet, vulnerability study on tourism in this case is still limited. Thus, this study aimed to determine the exposure of Ranau tourism to the 2015 earthquake disaster from tourism entrepreneurs' perspective. According to qualitative-thematic analysis, this study revealed significant level of exposure of Ranau tourism entrepreneurs to 2015 earthquake disaster overall and the Source component (tourism) lies within significant percentages, meanwhile Power component (social capital) showed insignificant level of exposure. Contextually, themes that are classified as weaknesses are the capitals that contribute to the exposure of Ranau tourism entrepreneurs, meanwhile strength capitals that are fabricated within Ranau tourism entrepreneurs would regulate the exposure and act as a catalyst to enhance their coping response. Importantly, these findings initiate a first step for Ranau tourism entrepreneurs to integrate natural disaster management into their development through vulnerability approach following the 2015 earthquake as a crucial part of sustainable tourism development. However, this study is only limited to Exposure element in analysing Ranau tourism vulnerability. Therefore, it is recommended that the analysis for the remaining elements in VFSTD (Sensitivity and Adaptation) be expanded to complete the vulnerability analysis of Ranau tourism entrepreneurs in the case of the 2015 earthquake disaster.

\section{Acknowledgements}

Authors wished to thank reviewers and editors for the comments on the improvement of this article.

\section{References}

Adger, W. N. (2006). Vulnerability. Global Environmental Change, 16(3), 268-281.

Adger, W. N. (2008). Resilience and vulnerability. In Leach, M. (Eds.), Reframing resilience: A Symposium Report (pg. 5-7). Brighton: STEPS Centre.
Allya, C. A., Bahari, F. B., Mohd Dahlan A., Malek, Mutang., J. A., Lailawati Madlan, \& Wan Anor Sulaiman. (2017). Pengalaman trauma dan daya tindak dalam kalangan Malim Gunung semasa bencana gempa bumi Sabah. In Rodeano Roslee, Felix Tongkul, Efren, H. F. W., H a z e ri in a Pungut \& Mohamed Ali Yusof Mohd Husin (Eds.), Bencana alam ke arah pengurusan bencana yang mapan (pg. 60-65). Universiti Malaysia Sabah: Pusat Kajian B e n c a n a Alam (NDRC) Universiti Malaysia Sabah.

Baker, K., \& Coulter, A. (2007). Terrorism and tourism: The vulnerability of beach vendors' livelihoods in Bali. Journal of Sustainable Tourism, 15(3), 249-266.

Becken, S., \& Hughey, K. F. D. (2013). Linking tourism into emergency management structures to enhance disaster risk reduction. Tourism Management, 36(2013), 77-85.

Becken, S., Mahon, R., Rennie, H. G., \& Shakeela, A. (2014). The tourism disaster vulnerability framework: An application to tourism in small island destinations. Natural Hazards, 71(1), 955-972.

Berkhout, F. (2008). Order in socio-technical systems: The dark side of Resilience. In Leach, M. (Eds.), Re-framing resilience: $A$ Symposium Report (pg. 11-12). Brighton: STEPS Centre.

Birkmann, J. (2006). Measuring vulnerability to natural hazards. Tokyo: United Nations University Press.

Blaikie, N. (2010). Designing social research ( $2^{\text {nd }}$ ed.). Cambridge: Polity Press.

Braun, V., \& Clarke, V. (2006). Using thematic analysis in psychology. Qualitative Research in Psychology, 3, 77-101.

Butler, R. W. (1999). Tourism: An evolutionary perspective. In. Nelson, J. G., Butler, R. W. $\&$ Wall, G. (Eds.), Tourism and sustainable development: A civic approach (2nd ed.). (33-62) Waterloo: University of Waterloo.

Calgaro, E., \& Lloyd, K. (2008). Sun, sea, sand and tsunami: Examining disaster 
vulnerability in the tourism community of Khao Lak, Thailand. Singapore Journal of Tropical Geography, 29(3), 288-306.

Calgaro, E., Lloyd, K., \& Dominey-Howes, D. (2014). From vulnerability to transformation: A framework for assessing the vulnerability and resilience of tourism destinations. Journal of Sustainable Tourism, 22(3), 341-360.

Campiranon, K., \& Scott, N. (2014). Critical success factors for crisis recovery management: A case study of Phuket hotels. Journal of Travel \& Tourism Marketing, 31(3), 313-326.

Chua, Y. P. (2014). Kaedah Penyelidikan ( $3^{\text {rd }}$ ed.). Selangor: McGraw Hill Education.

Cioccio, L., \& Michael, E. J. (2007). Hazard or disaster: Tourism management for the inevitable in Northeast Victoria. Tourism Management, 28(1), 1-11.

Clark, G., Jaeger, J., \& Corell, R. (2000). Assessing vulnerability to global environmental risks. Belfer Center for Science and International Affairs Discussion Paper 2000-12. Environment and Natural Resources Program, Kennedy School of Government, Harvard University, Cambridge. MA. Available at http:// ksgnotes1.harvard.edu/BCSIA/sust.nsf/ pubs/pub1/\$File/2000-12.pdf

Clark, W. C., \& Dickson, N. M. (2003). Sustainability Science: The emerging research program. Proceedings of the National Academy of Sciences of the United States, 100(14), 8059-8061.

Cohen, E. (2008). The tsunami waves and the paradisic cycle: The changing image of the Andaman Coastal Region of Thailand. Tourism Analysis, 13, 221-232.

Coleman, J. S. (1988). Social capital in the creation of human capital. American Journal of Sociology, 94, S95-S120.

Creswell, J. W. (2014). Research design: Qualitative, quantitative, and mixed methods approaches. Thousand Oaks, California: Sage Publications.

De Roo, G. (2012). Spatial planning, complexity and a world “out of equilibrium': Outline of a non-linear approach to planning. In. G. De Roo, J. Hillier, \& J. Van Wezemael (Eds.). Complexity and planning: Systems, assemblages and simulations (page. 129165). Farnham: Ashgate.

Dickinson, J. E., Filimonau, V., Hibbert, J. F., Cherrett, T., Davies, N., Norgate, S., \& Winstanley, C. (2017). Tourism communities and social ties: The role of online and offline tourist social ne t w o r k s in building social capital and sustainable practice. Journal of Sustainable Tourism 25(2), 163-180.

Dora, A. G. K., Tukiar, M. A., \& Zulhaimi, S. (2018). Structural deformation of staff's quarters SMK Ranau subjected to the 2015 Ranau earthquake using Ruaumoko 2D. AIP Conference Proceedings, pg. 0200381 - 020038-6

Dredge, D., \& Jenkins, J. (2003). Destination place identity and regional tourism planning. Tourism Geographies, 5(4), 383407.

Dwyer, L., Edwards, D., Mistilis, N., Roman, C., \& Scott, N. (2008). Destination and enterprise management for a tourism future. Tourism Management, 30, 63-74.

Eakin, H. L., \& Luers, A. L. (2006). Assessing the vulnerability of social-environment systems. Annual Review of Environment and Resource, 31, 365-394.

Eraqi, M. I. (2006). Tourism services quality (tour servqual) in Egypt: The viewpoints of external and internal customers. Benchmarking: An International Journal, 13(4), 469-492.

Espiner, S., Orchiston, C., \& Higham, J. (2017). Resilience and sustainability: A complementary relationship? Towards a practical conceptual model for the sustainability-resilience nexus in tourism. 
Journal of Sustainable Touris, 25(10), $1385-1400$.

Faulkner, B. (2001). Towards a framework for tourism disaster management. Tourism Management, 22(2), 135-147.

Felix Tongkul, Rodeano Roslee, Baba Musta, Ismail Abdul Rahim, Kawi Bidin, Hennie Fitria W.S. Erfen \& Mohamed Ali Yusuf Mohd.Husin. (2017). Perancangan pembangunan di kawasan berisiko gempa bumi: Pembelajaran dari gempa bumi 5 Jun 2015 Ranau, Sabah. Dlm. Rodeano Roslee, Felix Tongkul, Efren, H. F. W., Hazerina Pungut \& Mohamed Ali Yusof Mohd Husin (Pnyt.), Bencana alam ke arah pengurusan bencana yang mapan (pg. 49-49). Universiti Malaysia Sabah: Pusat Kajian Bencana Alam (NDRC) Universiti Malaysia Sabah.

Felix Tongkul. (2015). The 2015 Ranau earthquake: Cause and impact. Sabah Society Journal, 32(2015), 1-28.

Guest, G., Bunce, A., \& Johnson, L. (2006). How many interviews are enough? An experiment with data saturation and variability. Field Methods, 18(1), 59-82.

Guo, Y., Zhang, J., Zhang, Y., \& Zheng, C. (2018). Examining the relationship between social capital and community residents' perceived resilience in tourism destinations. Journal of Sustainable Tourism, 26(6), 973-986.

Handmer, J., Coate, B., \& Choong, W. (2007). The Indian Ocean tsunami: Local resilience in Phuket. In Mcfadden, L., Nicholls, R. \& Penning-Rowsell, E. (Eds.), Managing coastal vulnerability (pg. 121-139). Oxford: Elsevier.

Higgins-Desbiolles, F. (2010). The elusiveness of sustainability in tourism: The culture ideology of consumerism and its implications. Tourism and Hospitality Research, 10, 116-129.

Hwang, D., \& Stewart, W. P. (2017). Social capital and collective action in rural tourism. Journal of Travel Research, 56(1), 81-93.

Indan, E., Rodeano Roslee, Felix Tongkul \& Simon, N. (2018). Earthquake vulnerability assessment (EVAS): Analysis of environmental vulnerability and social vulnerability in Ranau Area Sabah Malaysia. Geological Behavior, 2(1), 24-28

Jager, J., Kok, M. T. J., Mohamed-Katerere, J. C., Karlsson, S. I., Lüdeke, K. B., Dabelko, G. D., Thomalla, F., De Soysa, I., Chenje, M., Filcak, R., Koshy, L., Martello, M. L., Mathur, V., Mareno, A. R., Nararin, V., Sietz, D., Al Ajmi, D. N., Callister, K., De Oliveira, T., Fernandez, N., Gasper, D., Giada, S., Gorobets, A., Hilderink, H., Krishnan, R., Lopez, A., Nakyeyune, A., Ponce, A., Strasser, S., \& Wonink, S. (2007). Vulnerability of people and the environment: Challenges and opportunities. Dlm. UNEP (Pnyt.), Global Environment Outlook 4: Environment for development (hlm. 301-360). Nairobi: UNEP.

Jiang, D. M., \& Liu, B. (2009). Countermeasures of adaptation to climate change: Establishment and application for implementation matrix. Ecology Economy, 5(2), 102-111.

Jiang, Y., \& Ritchie, B. W. (2017). Disaster collaboration in tourism: Motives, impediments and success factors. Journal of Hospitality and Tourism Management, 31(2017), 70-82.

Kasperson, J. X., Kasperson, R. E., Turner, B., Hsieh, W., \& Schiller,

A. (2012). Vulnerability to global environmental change. In Kasperson, R. E., Kasperson, J. (Eds.), The social contours of risk: Volume II: Risk analysis, corporations and the globalization of risk (245-285). London: Routledge

Kato, K. (2017). Debating sustainability in tourism development - resilience, traditional knowledge \& community, a post-disaster perspective. Tourism Planning and Development, 3(11), 1-13. 
Lew, A. A. (2003). Editorial: Tourism in troubled times. Tourism Geographies, 5(3), 255-256.

Liu, J., Qu, H., Huang, D., Chen, G., Yue, X., Zhao, X., \& Liang, Z. (2014). The role of social capital in encouraging residents' proenvironmental behaviours in communitybased ecotourism. Tourism Management, 41, 190-201.

Maxwell, J. A. (2005). Qualitative Research Design: An interactive approach ( $2^{\text {nd }} \mathrm{ed}$.). Thousand Oaks, California: Sage Publications.

Matusin, A. M. R. A., Othman, N., Siwar, C., \& Halim, S. A. (2019a). Pelancongan Lestari Malaysia mendepani bencana alam: Kes gempa bumi Ranau (2015). Asian Journal of Environment, History and Heritage, 3(1),15-23.

Matusin, A. M. R. A., Siwar, C., \& Halim, S. A. (2019b). Vulnerability framework of tourism to natural disasters. Geografia, 15(4), 137-150.

Miller, F., Osbahr, H., Boyd, E., Thomalla, F., Bharwani, S., Ziervogel, G., \& Nelson,

D. (2010). Resilience and vulnerability: Complementary or conflicting concepts? Ecology and Society, 15(3), 11.

Miller, G. A., \& Ritchie, B. W. (2003). A farming crisis or a tourism disaster? An analysis of the foot and mouth disease in the UK. Current Issues in Tourism, 6(2), 150-171.

Mohd Irwan Adiyanto, Taksiah Majid \& Fadzli Mohamed Nazri. (2017). Non-structural damages of reinforced concrete buildings due to 2015 Ranau Earthquake. AIP Conference Proceedings, pg. 090002-1 090002-6

Morgan, D., \& Fluker, M. (2003). Risk management for Australian commercial adventure tourism operations. Journal of Hospitality and Tourism Management, 10(1), 46-50.

Nelson, D. R., Adger, W. N., \& Brown, K. (2007). Adaptation to environmental change: Contributions of a resilience framework. Annual Review of Environment and Resources, 32(11), 395-419.

Noor Fzlinda Fabeil, Kamarul Mizal Marzuki, Izyanti Awang Razli, Mohd Rizman Abdul Majid \& Marry Tracyanal Pawan. (2018). The impact of earthquake on small business performance: Evidence from small accommodation services in Ranau Sabah. International Academic Journal of Business Management, 5(3), 163-175.

Nunkoo, R. (2017). Governance and sustainable tourism: What is the role of trust, power and social capital? Journal of Destination Marketing and Management, 6(4), 277285.

Nyaupane, G. P., \& Chhetri, N. (2009). Vulnerability to climate change of naturebased tourism in the Nepalese Himalayas. Tourism Geographies, 11(1), 95-119.

O’Brien, K. (2006). Editorial: Are we missing the point? Global environmental change as an issue of human security. Global Environmental Change, 16, 1-3.

Orchiston, C. (2012). Seismic risk scenario planning and sustainable tourism management: Christchurch and the alpine fault zone, South Island, New Zealand. Journal of Sustainable Tourism, 20(1), 5979.

Orchiston, C. (2013). Tourism business preparedness, resilience and disaster planning in a region of high seismic risk: The case of the Southern Alps, New Zealand. Current Issues in Tourism 16(5), 477-494.

Pelling, M. (2003). The vulnerability of cities: Natural disasters and social resilience. London: Earthscan.

Pelling, M. (2010). Adaption to climate change: From resilience to transformation. London: Routledge.

Poortinga, W. (2012). Community resilience and health: The role of bonding, bridging and linking aspects of social capital. Health \& Place, 18(2), 286-295. 
Portes, A. (2000). The two meanings of social capital. Sociological Forum, 15(1), 1-12.

Prideaux, B., Laws, E., \& Faulkner, B. (2003). Events in Indonesia: Exploring the limits to formal tourism trends forecasting methods in complex crisis situations. Tourism Management, 24, 475-487.

Rabiehtul Abu Bakar, Tajul Anuar Jamaluddin, Zulkarnian Abd Rahman, Khamarrul Azahari Razak, Zamri Ramli, Zakaria Mohamad, \& Felix Tongkul. (2015). Remotely sensed geospatial analysis towards disaster: Kundasang tectonically active zone Sabah. Seminar Bencana Alam 2015, pg. 30.

Ranau District Office. (2011). Pelancongan Daerah Ranau http://ww2.sabah.gov.my/ pd.rnu/pelancongan.html [12 Jun 2018]

Ranau District Office. (2015). Taklimat Pembangunan Daerah Ranau. Slaid. Daerah Ranau: Pejabat Daerah Ranau.

Rigg, J., Grundy-Warr, C., Law, L., \& TanMullins, M. (2008). Grounding a natural disaster: Thailand and the 2004 tsunami. Asia Pacific Viewpoint, 49(2), 137-154.

Ritchie, B. W. (2008). Tourism disaster planning and management: From response and recovery to reduction and readiness. Current Issues in Tourism, 11(4), 315-348.

Ruiu, M. L., Seddaiu, G., \& Roggero, P. P. (2017). Developing adaptive responses to contextual changes for sustainable agricultural management: The role of social capital in the Arborea district ( Sardinia, Italy). Journal of Rural Studies, 49, 162170.

Rygel, L., O’Sullivan, D., \& Yarnal, B. (2006). A method for constructing a social vulnerability index: An application to hurricane storm surges in a developed country. Mitigation and Adaptation Strategies for Global Change, 11(3), 741764.

Sabah Park. (2018). Kinabalu Park and Porings Hot Spring (Day Trip, Overnight and
Climbers). Visitors Figure to Sabah Parks. Kota Kinabalu, 1 November 2018.

Sharpley, R. (2005). The tsunami and tourism: A comment. Current Issues in Tourism, 8(4), 344-349.

Singh, S. B. S., Rathakrishnan, B., Dg. Norizah Ag. Kiflee, Rosli Talip, Zulfikar \& Lan, A. S. S. (2018). Penilaian pengetahuan dan kesediaan menghadapi bencana gempa bumi dalam kalangan guru sekolah di Ranu Sabah. Journal of Social Sciences and Humanities, 13(2), 073-088.

Szreter, S., \& Woolcock, M. (2004). Health by association? Social capital, social theory, and the political economy of public health. International Journal of Epidemiology, 33(4), 650-667.

Takano, S., \& Saito, T. (2017). Analysis of a school building damaged by the 2015 Ranau earthquake Malaysia. AIP Conference Proceedings, pg. 120004-1-120004-8.

Taylor, S. R. (2017). Issues in measuring success in community-based Indigenous tourism: Elites, kin groups, social capital, gender dynamics and income flows. Journal of Sustainable Tourism, 25(3), 433-449.

Tsai, C. H., \& Chen, C. W. (2010). An earthquake disaster management mechanism based on risk assessment information for the tourism industry-a case study from the island of Taiwan. Tourism Management, 31(4), 470481.

Tsao, C-Y., \& Ni, C-C. (2016). Vulnerability, resilience, and the adaptive cycle in a crisis prone tourism community. Tourism Geographies, 18(1), 80-105.

Turner, B. L. (2010). Vulnerability and resilience: Coalescing or paralleling approaches for sustainability science? Global Environmental Change, 20(4), 570576.

Turner, B. L., Kasperson, R. E., Matson, P. A., McCarthy, J. J., Corell, R. W., Christensen, L., Eckley, N., Kasperson, J. X., Luers, A., Martello, M. L., Polsky, C., Pulsipher, 
A., \& Schiller, A. (2003). A framework for vulnerability analysis in sustainability science. Proceedings of the National Academy of Sciences, 100(14), 8074-8079.

United State Geological Survey. (2015). M 6.0 - 14km WNW of Ranau, Malaysia https://earthquake.usgs.gov/earthquakes/ eventpage/us20002m5s/shakemap/ inensity[17Mei 2018]

Veal, A. J. (2011). Research methods for leisure and tourism: A practical guide. England: Pearson Education Limited.

Vogel, C., \& O’Brien, K. (2004). Vulnerability and global environmental change: Rhetoric and reality. AVISO - Informational
Bulletin on Global Environmental Change and Human Security, 13(3), 1-8.

Webersik, C., Esteban, M., \& Shibayama, T. (2010). The economic impact of future increase in tropical cyclones in Japan. Natural Hazards, 55(2), 233-250.

Woolcock, M., \& Narayan, D. (2000). Social capital: Implication for development theory, research and policy. The World Bank Research Observer, 15(2), 225-249.

World Tourism Organization. (2013). Sustainable tourism for development guidebook 2013. Madrid: UNWTO.

World Tourism Organization. (2018). UNWTO tourism highlights 2018 edition. Madrid: UNWTO. 